\title{
Organizational structure and seasonal indices in arrivals and prices of agricultural commodities in Kolhapur APMC market
}

\author{
H.P. THAKARE, K.S. DAUNDKAR, U.S. BONDAR AND SUPRIYA D. KASHID
}

Received : 12.07.2016; Revised : 30.08.2016; Accepted : 17.09.2016

\begin{abstract}
The study revealed that, organizational structure and composition was established well according to the Maharashtra Agricultural Produce Marketing (Regulation) Act 1963. The open auction method was strictly followed in the market, the overall conduct and law and administrative promptness was seen satisfactory. This study was suggested that the wheat growers should bring wheat for sell in the APMC, Kolhapur during the month of December to March. The paddy growers shall bring paddy for the sell in the APMC, Kolhapur during the month of August to December. In case of the onion growers shall bring onion for sell in APMC, Kolhapur during September to December. Potato can be brought for sell in APMC, Kolhapur during the month of September to December and the groundnut during April and September to January and in case jaggery for sell in APMC, Kolhapur during August and October to December in order to get good prices for their produce.
\end{abstract}

KEY WORDS : Seasonal indices, Arrivals, Prices, APMC

How to cite this paper : Thakare, H.P., Daundkar, K.S., Bondar, U.S. and Kashid, Supriya D. (2016). Organizational structure and seasonal indices in arrivals and prices of agricultural commodities in Kolhapur APMC market. Internat. J. Com. \& Bus. Manage, 9(2) : 227233, DOI: 10.15740/HAS/IJCBM/9.2/227-233. 